Portland State University

PDXScholar

\title{
Extensive Aerosol Optical Properties and Aerosol Mass Related Measurements During TRAMP/ TexAQS 2006 - Implications for PM Compliance and Planning
}

Monica Elizabeth Wright

Portland State University, monica.e.wright@gmail.com

Dean B. Atkinson

Portland State University, atkinsond@pdx.edu

Luke Ziemba

University of New Hampshire - Main Campus

Robert Griffin

University of New Hampshire - Main Campus

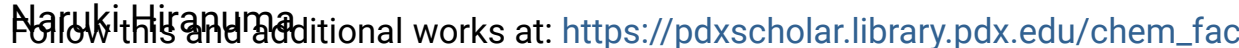
Toyas A \& M University - College Station

Part of the Atmospheric Sciences Commons, Chemistry Commons, and the Environmental Monitoring Commons

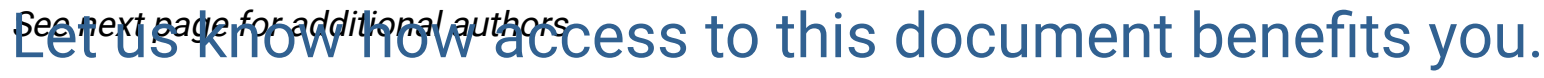

\section{Citation Details}

Wright, M. E., Atkinson, D. B., Ziemba, L., Griffin, R., Hiranuma, N., Brooks, S., \& ... Kelley, P. (2010). Extensive aerosol optical properties and aerosol mass related measurements during TRAMP/TexAQS 2006 - Implications for PM compliance and planning. Atmospheric Environment, 44(33), 4035-4044.

This Article is brought to you for free and open access. It has been accepted for inclusion in Chemistry Faculty Publications and Presentations by an authorized administrator of PDXScholar. Please contact us if we can make this document more accessible: pdxscholar@pdx.edu. 


\section{Authors}

Monica Elizabeth Wright, Dean B. Atkinson, Luke Ziemba, Robert Griffin, Naruki Hiranuma, Sarah D.

Brooks, James Flynn, Ryan Perna, Bernhard Rappenglück, Winston Luke, and Paul Kelley 


\title{
Extensive aerosol optical properties and aerosol mass related measurements during TRAMP/TexAQS 2006 - Implications for PM compliance and planning
}

\author{
Monica E. Wright ${ }^{a}$, Dean B. Atkinson ${ }^{\mathrm{a}, *}$ Luke Ziemba $^{\mathrm{b}}$, Robert Griffin ${ }^{\mathrm{b}, 1}$, Naruki Hiranuma ${ }^{\mathrm{c}}$, \\ Sarah Brooks ${ }^{c}$, Barry Lefer ${ }^{d}$, James Flynn ${ }^{d}$, Ryan Perna ${ }^{d}$, Bernhard Rappenglück ${ }^{d}$, Winston Luke ${ }^{e}$, \\ Paul Kelley ${ }^{\mathrm{e}}$ \\ a Department of Chemistry Portland State University, Portland, OR 97207-0751, USA \\ ${ }^{\mathrm{b}}$ Climate Change Research Center, University of New Hampshire, Durham, NH 03824, USA \\ ${ }^{c}$ Department of Atmospheric Sciences Texas AEM University College Station, TX 77843, USA \\ ${ }^{\mathrm{d}}$ Department of Earth and Atmospheric Sciences University of Houston, Houston, TX 77004-2610, USA \\ e NOAA/Air Resources Laboratory, Silver Spring, MD 20910, USA
}

\section{A R T I C L E I N F O}

\section{Article history:}

Received 1 October 2008

Received in revised form 16 December 2008

Accepted 17 December 2008

\section{Keywords:}

Urban air quality

PM

Aerosol optical properties

AMS

Particle size distribution

\begin{abstract}
A B S T R A C T
Extensive aerosol optical properties, particle size distributions, and Aerodyne quadrupole aerosol mass spectrometer measurements collected during TRAMP/TexAQS 2006 were examined in light of collocated meteorological and chemical measurements. Much of the evident variability in the observed aerosolrelated air quality is due to changing synoptic meteorological situations that direct emissions from various sources to the TRAMP site near the center of the Houston-Galveston-Brazoria (HGB) metropolitan area. In this study, five distinct long-term periods have been identified. During each of these periods, observed aerosol properties have implications that are of interest to environmental quality management agencies. During three of the periods, long range transport (LRT), both intra-continental and intercontinental, appears to have played an important role in producing the observed aerosol. During late August 2006, southerly winds brought super-micron Saharan dust and sea salt to the HGB area, adding mass to fine particulate matter $\left(\mathrm{PM}_{2.5}\right)$ measurements, but apparently not affecting secondary particle growth or gas-phase air pollution. A second type of LRT was associated with northerly winds in early September 2006 and with increased ozone and sub-micron particulate matter in the HGB area. Later in the study, LRT of emissions from wildfires appeared to increase the abundance of absorbing aerosols (and carbon monoxide and other chemical tracers) in the HGB area. However, the greatest impacts on Houston $\mathrm{PM}_{2.5}$ air quality are caused by periods with low-wind-speed sea breeze circulation or winds that directly transport pollutants from major industrial areas, i.e., the Houston Ship Channel, into the city center.
\end{abstract}

(c) 2009 Elsevier Ltd. All rights reserved.

\section{Introduction}

The Texas Air Quality Study II (TexAQS II) Radical and Aerosol Measurement Program (TRAMP) sub-study was conducted during a six week period (14 August through 30 September 2006) in Houston as part of the TexAQS 2006 field intensive. The focus of the TRAMP project was to collect meteorological and primary and secondary pollutant concentration data in order to help the Texas Commission on Environmental Quality (TCEQ) in its efforts to craft

\footnotetext{
* Corresponding author. Tel.: +1 (503) 725 8117; fax: +1 (503) 7259525.

E-mail address: AtkinsonD@pdx.edu (D.B. Atkinson).

${ }^{1}$ Currently at Department of Civil and Environmental Engineering Rice University, Houston, TX 77005.
}

a Strategic Implementation Plan (SIP) for meeting air quality goals. Houston has frequently been unable to attain the federally mandated ozone standard and appears to be close to non-attainment of the new fine particulate matter $\left(\mathrm{PM}_{2.5}\right)$ standard. (Bates et al., 2008) Recent changes in the National Ambient Air Quality Standards (NAAQS) require longer averaging times, so broader geographical regions could influence air pollutant concentrations. The annual average $\mathrm{PM}_{2.5}$ standard is $15 \mu \mathrm{g} \mathrm{m}^{-3}$, as determined by the three-year average of annual mean $\mathrm{PM}_{2.5}$ concentrations; and the 24-h $\mathrm{PM}_{2.5}$ standard is $35 \mu \mathrm{g} \mathrm{m}^{-3}$ based on the three-year average of the 98 th percentile of 24-h concentrations. (EPA, 2007) Because Eastern Texas and the Houston-Galveston-Brazoria (HGB) area in particular are home to a large portion of the state's business activity and the second largest population center in Texas, understanding both pollutant concentrations and potential long range 
transport (LRT) sources to the area is essential for protecting both the quality of life and the economic climate.

Identifying the most effective and efficient approaches to improving air quality requires a sound understanding of the emissions and atmospheric processes that lead to air pollution. The short time span of the TRAMP study does not allow the seasonal analysis needed for a comprehensive aerosol climatology, but by identifying meteorological parameters and source locations, it is possible to use the data to begin to infer specific conditions in Houston that lead to 'bad' air quality days. For example, during warm periods, Houston often experiences a circulating land/sea breeze that is thought to cause pollutant recirculation and enhance ozone (and perhaps $\mathrm{PM}_{2.5}$ ) formation. (Byun et al., 2007; Daum et al., 2004) The measurements of the ambient aerosol collected during the TRAMP study serve as a representative sample of a late summer period when ozone levels are typically near or above the NAAQS (effectively a mid-day 8-hour average of 85 ppbv or above).

This paper focuses on aerosol properties that are related to PM mass concentration because the regulatory structure is currently based on this quantity. Measurements presented include volume particle size distributions (PSDs) by two commercially produced (Grimm Aerosol Technik GmbH \& Co.) instruments, size- and composition-segmented non-refractory aerosol mass by the Aerodyne quadrupole aerosol mass spectrometer (Q-AMS), and the extensive (depending on particle mass concentration) aerosol optical properties extinction coefficient $\left(b_{\text {ext }}\right)$ measured in the visible and near-infrared spectral regions at $532 \mathrm{~nm}$ and $1064 \mathrm{~nm}$ with a pulsed cavity ring-down transmissometer (CRDT) and scattering coefficient $\left(b_{\text {scat }}\right.$ ) measured at $530 \mathrm{~nm}$ by a nephelometer (collectively termed the CRDT/N). The intensive aerosol optical property Ångström exponent, a measure of the dependence of extinction on wavelength, was also studied during TexAQSGoMACCS 2006. (Atkinson et al., in preparation)

The data were analyzed for a number of likely temporal trends, i.e., diurnal, weekly, weekday/weekend, synoptic-weather pattern related, etc. Several trends were identified and are discussed in detail. This analysis indicated no evidence for a weekly trend or a weekday/weekend signature. The longer term trends in the data are thought to reflect changes in the aerosol background associated with changes in the synoptic-weather patterns that facilitate LRT, connecting Houston with sources as far away as the African continent. A five-week period from 25 August 2006 to 24 September 2006 (when most of the instruments used were operating properly) was selected and divided into periods that have somewhat distinct character and associated meteorology.

\section{Experiment}

\subsection{TRAMP site description}

The data sets were collected by a suite of instruments located in air-conditioned enclosures atop the $\sim 70$-m high North Moody Tower dormitory building on the University of Houston (UH) campus in Houston, TX. Although this building is near the center of the Houston city limits, it is far enough away from highways and significant industrial sources and high enough to avoid direct influence by any local point source. (Flynn, 2008; Lefer and Rappenglück, 2008)

The inlets for each instrument were mounted above the roof top to minimize any ground interference; whenever possible, the EPA ambient air measurement guidelines were followed. (EPA, 1995) Because the temperature in the climate-controlled trailers was usually below the ambient temperature, sample lines were insulated or heated to avoid condensation and line losses of both particles and trace gas species. A comprehensive list of the study participants, (including instruments deployed and properties measured) and the overall study objectives are summarized in the overview publication for this special issue. (Lefer and Rappenglück, 2008).

\section{2. $C R D T / N$ instrument description}

Extensive aerosol optical properties were measured by a custom-built CRDT. (Smith and Atkinson, 2001) This instrument measures bext simultaneously at wavelengths of $532 \mathrm{~nm}$ and $1064 \mathrm{~nm}$ using the cavity ring-down approach as previously described and validated. (Radney et al., 2009; Smith and Atkinson, 2001) The scattering coefficient of aerosols is also measured nearly simultaneously at $530 \mathrm{~nm}$ by passing the aerosol from the CRDT to an attached nephelometer (Radiance Research Co., M903-530, Seattle, WA) forming the tandem CRDT/N instrument. The cavity temperature and relative humidity $(\mathrm{RH})$ were monitored within the aerosol flow system between the transmissometer and the nephelometer using a combination temperature/RH sensor (Vaisala, Inc., Humitter 50Y). The temperature was generally between the outside air temperature and that inside the trailer, a reflection of the inability to completely insulate the instrument from the air conditioning. The RH was often lower than ambient, generally below $50 \%$, with small oscillations that were synchronous with the air conditioner cycle. For the period presented in this paper, the aerosol was drawn through a Teflon coated aluminum cyclone inlet (URG Inc., model URG-2000-30 EN) with a nominal cut-point at $2.5 \mu \mathrm{m}$ aerodynamic diameter at a flow rate of $10 \mathrm{~L}$ per minute (lpm). However, the CRDT/N operates at a flow rate of $5 \mathrm{lpm}$, which should result in a cut-point closer to $4 \mu \mathrm{m}$. The aerosol flow was also drawn through approximately 25 feet of $3 / 8$ inch outer diameter copper tubing before entering the CRDT/N instrument, resulting in the possibility of some loss of particles. The total flow from the inlet and connecting tubing through both instruments was produced by a diaphragm pump, controlled with a needle valve, and measured with a bubble flow-meter (A.P. Buck Inc., miniBUCK M-30).

The scattering coefficient measurement by the nephelometer is known to suffer from a low bias when applied to large particles. This bias has not been well-quantified for the Radiance Research nephelometer but is known to be larger than that of the more commonly used TSI model 3563 Integrating Nephelometer. (Heintzenberg et al., 2006) A useable correction factor for the M903 will be produced using the results of Heintzenberg et al. (2006), coincident measurements of the PSD, and the CRDT-measured Ångström exponent. (Anderson and Ogren, 1998; Heintzenberg et al., 2006) The uncorrected scattering coefficients presented in this paper are expected to be smaller than the true values and will only be used in relative comparisons to draw qualitative conclusions.

\subsection{Commercially produced instruments}

An Aerodyne Q-AMS produced chemically speciated mass concentrations for the common aerosol components (sulfate, organic, ammonium, and nitrate). This instrument was operated as described by Ziemba et al. (2010). The data were segregated by composition and binned aerosol vacuum aerodynamic diameter The Q-AMS is insensitive to refractory components, including dust, sea salt, and elemental carbon, all of which are observed by other instruments during portions of this study. The inlet design for the Q-AMS admits low RH, sub-micron aerosols. Details describing design and operation of the Q-AMS are given in Jayne et al. (2000) and Jimenez et al. (2003). 
A Sequential Mobility Particle Sizer from GRIMM Technologies, Inc. was operated throughout the project. The SMPS consists of a Differential Mobility Analyzer (Model DMA-L) and an Ultrafine Particle Counter (Model 5.403). The SMPS recorded a full PSD from $11.1 \mathrm{~nm}$ to $521 \mathrm{~nm}$ in 38 size bins approximately every 7 min for the majority of the study period. The SMPS determines the electrical mobility diameter of a particle, which is the diameter of a sphere with the same migration velocity in a constant field as the sampled particle. For spherical particles, the electrical mobility diameter is equal to the volume equivalent diameter, which aids in the calculation of volume density. (DeCarlo et al., 2004) In addition, a laserbased Aerosol Spectrometer (GRIMM Model 1.108 PAS) system recorded a full coarse mode particle distribution consisting of 15 size bins from $0.3 \mu \mathrm{m}$ to $22 \mu \mathrm{m}$ every minute. It can be assumed that the optical particle size measured by the PAS is equivalent to the volume equivalent or geometric diameter of the particle. (Peters et al., 2006) The inlet used for the TRAMP study was subsequently found to suffer from increasing losses of the larger particle sizes. A thorough investigation of the inlet transmission as a function of particle size allowed for the correction of the raw data for the loss effects with maximum uncertainty that depends on particle size. In this study, only data from the smallest size bins of the GRIMM 1.108 were used. For each of these diameter bins (1.0-1.6, 1.6-2.0, 2.0-3.0, and $3.0-4.0 \mu \mathrm{m})$, the particle losses and corrections were $\leq 10 \%$.

Volatile organic compounds (VOCs) including toluene and isoprene were measured online every hour using a Perkin-Elmer VOC-system consisting of a Clarus 500 gas chromatograph with a heart cut device and equipped with two flame ionization detectors and two analytical columns (Alumina PLOT column and BP-1) for multi-dimensional gas chromatography. Air samples were preconcentrated for $40 \mathrm{~min}$ on a Peltier-cooled cold trap at $-30^{\circ} \mathrm{C}$ and subsequently desorbed at $325{ }^{\circ} \mathrm{C}$ in a backflush mode by a Turbomatrix 650 Automatic Thermal Desorber. More details of the analysis can be found in Leuchner and Rappenglück (2010).

Carbon monoxide was measured with a commercial nondispersive infrared, gas filter correlation spectrometer (Model 48s, Thermo Electron Corp., Waltham, MA) modified for high sensitivity. Sulfur dioxide was measured with a modified commercial pulsed fluorescence detector (Model 43s, Thermo Electron Corp., Waltham, MA). Reactive nitrogen compounds ( $\mathrm{NO}, \mathrm{NO}_{x}, \mathrm{NO}_{y}$ ) were measured with a dual channel ozone chemiluminescence detector. One channel was dedicated to continuous measurements of $\mathrm{NO}_{y}$ with a molybdenum converter heated to $350{ }^{\circ} \mathrm{C}$. The second channel alternately measured $\mathrm{NO}$ and $\mathrm{NO}_{x}$ using a custom LEDbased photolytic converter; $\mathrm{NO}_{2}$ was calculated by difference.

\section{Results and discussion}

\subsection{Whole study temporal properties}

Hourly averaged data for the whole study period for the three optical properties, the SMPS, the Q-AMS, the TCEQ Continuous Air Monitoring Stations (CAMS) network (including $\mathrm{PM}_{2.5}$ mass measurements by tapered element oscillating microbalance devices; data available for download at http://www.tceq.state.tx.us/nav/ data/pm25.html), and toluene and isoprene are shown in Fig. 1. The visible aerosol extinction coefficient exhibits a downward trend, with a minimum in the 16 September to 24 September 2006 time period. The minimum (also seen in the chemical measurements in the bottom panel of Fig. 1) is coincident with increasing wind speeds (not shown) during this period. Strong southerly winds are presumed to have a clearing effect on the chemical pollutants in HGB (Rappenglück et al., 2008), including aerosols and their precursors, while simultaneously increasing depositional losses near the surface. The general agreement of the Q-AMS total mass with the SMPS-derived mass concentration is compelling evidence that both instruments tracked the sub-micron PM mass at the TRAMP site during the study. In this context, the Q-AMS total mass is computed by summation over all size bins and chemical components. The SMPS mass concentration is produced by first computing a volume concentration from the binned number concentration data and multiplying it by a composition-weighted density varying from $1.2 \mathrm{~g} \mathrm{~cm}^{-3}$ for pure organics to $1.7 \mathrm{~g} \mathrm{~cm}^{-3}$ for sulfates, using the composition from the Q-AMS. Throughout the study period, significant variations in the composition were observed, ranging from $74 \%$ sulfate to as much as $97 \%$ organic. The similarity of the two mass measurements at the TRAMP site to those from the TCEQ CAMS network is evidence that the measurements at the TRAMP site are representative of a larger aerosol airmass over much of the HGB area during this time period. The CAMS data shown here are averages of nine stations in and around Houston, including one in Conroe, TX, to the north of Houston, giving good spatial coverage of the HGB metropolitan area. The correlation of the individual CAMS stations with the average was also verified. Differences during the two times when the CAMS network $\mathrm{PM}_{2.5}$ concentrations are clearly larger than the other two measurements in the middle panel of Fig. 1 are attributed to the presence of super-micron aerosols, as explained below.

Another expected temporal trend is a diurnal cycle that is sometimes discernible (for the aerosols) in the $532 \mathrm{~nm}$ extinction coefficient data. Diurnal box and whisker plots (not shown) of the two $b_{\text {ext }}$ sets and the $b_{\text {scat }}$ data for the whole study period did not show a clear trend, with the exception of small increases during the morning (near rush hour). This probably indicates that large variations between days mask the variation within days. When compared with this analysis, other aerosol measurements demonstrated a clearer diurnal pattern and morning rush hour peak. (Ziemba et al., 2010) Of all the measurements considered in this study, isoprene shows the clearest diurnal trend. This trend is likely due to the strong dependence of isoprene concentration on temperature and light intensity, (Guenther et al., 1993) but the isoprene cycle is out of phase with that of $b_{\text {ext }}(532 \mathrm{~nm})$. To try to verify the diurnal variation that can be seen in the optical data at $532 \mathrm{~nm}$, the three aerosol optical property time series data sets ( $b_{\text {ext }}$ at $1064 \mathrm{~nm}$ and $532 \mathrm{~nm}$ and $b_{\text {scat }}$ at $530 \mathrm{~nm}$ ) were each divided by a $24-h$ moving window average centered on the given time point. A subset of the data is shown in Fig. 2 as the red, green, and blue traces; most of the difference between the extinction and scattering coefficients and much of the longer term variability are removed by the normalization procedure, leaving a clear periodic diurnal variation that we postulate is mainly due to changes in the height of the planetary boundary layer (PBL). The rest of the dataset showed similar behavior. The PBL heights shown in Fig. 2 were determined from rawinsondes that were launched from the UH campus twice per day at 0700 and 1900 CDT (Central Daylight Time) from 01 August to 30 September 2006. On selected days with high ozone forecasts (8-h averages greater than $85 \mathrm{ppbv}$ ), additional rawinsondes were launched at 0500, 1000, 1300, 1600, and 2200 CDT in order to capture the detailed evolution of the PBL growth. (Rappenglück et al., 2008) The presumed behavior of decreasing aerosol extinction during growth of the mixed layer is verified. This pattern establishes a minimum in the aerosol optical properties during the mid-afternoon on many days when several of the chemical species (e.g., isoprene, $\mathrm{OH}, \mathrm{HO}_{2}$, and ozone) peak.

\subsection{Multi-day period structures}

Because there was little indication of a weekday/weekend trend in the aerosol properties the remaining analyses focus on other variable factors (chiefly meteorological effects). The study period has been 


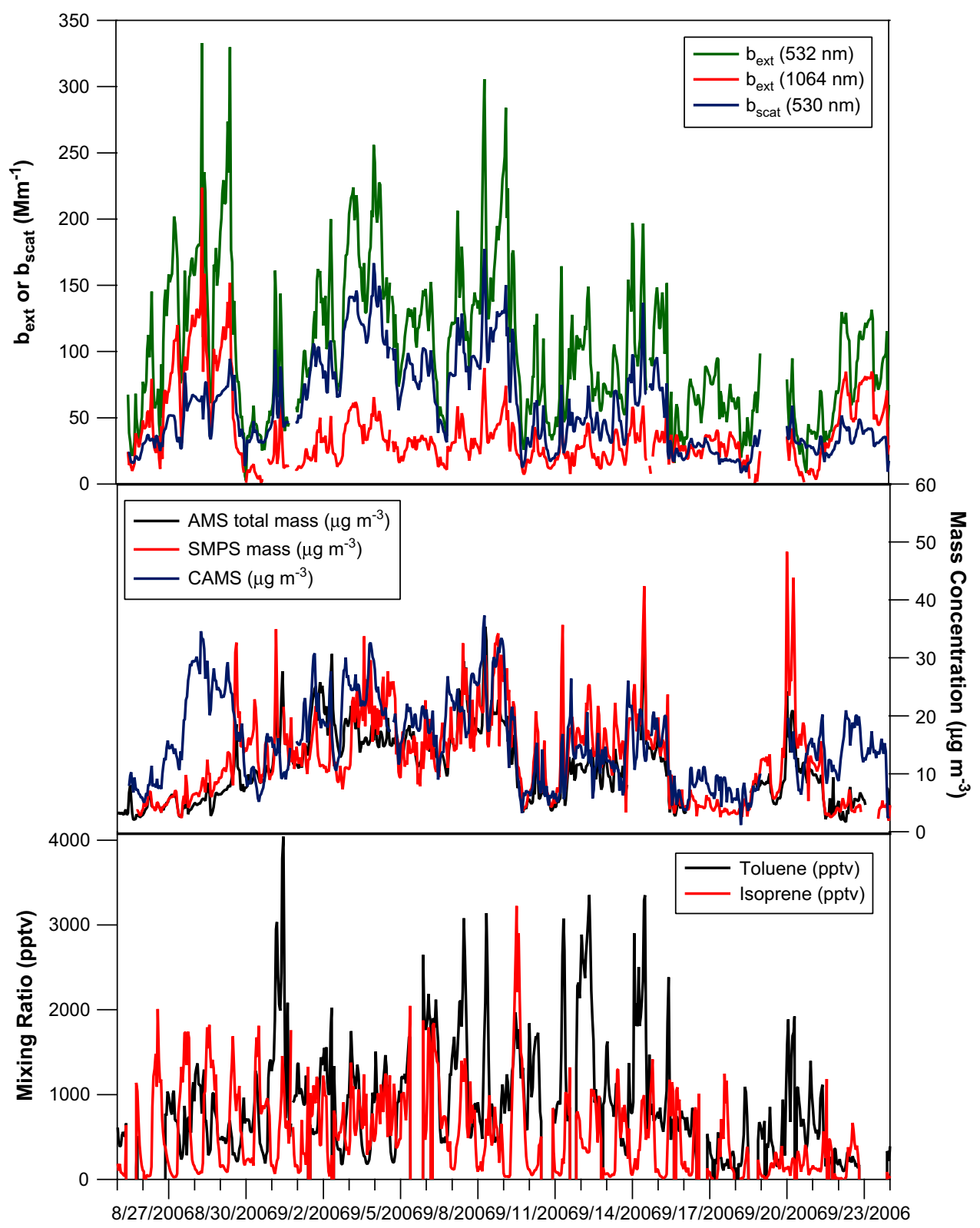

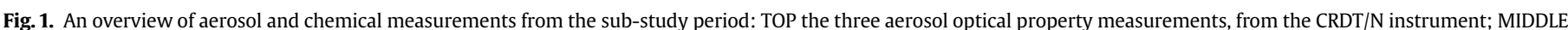

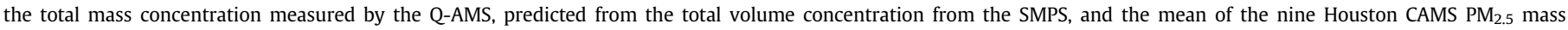
instruments; and BOTTOM the mixing ratios for isoprene and toluene. (Leuchner and Rappenglück, 2010).

divided into five periods, as shown in Table 1, that have different aerosol and/or chemical properties, generally linked to changes in the wind direction. Note that some conclusions below are based on wind speed and direction measured approximately at ground level $(\sim 70 \mathrm{~m}$ ASL) that might not be representative of synoptic patterns. Consideration of a larger set of meteorological measurements would improve confidence in the classification of the periods. The wind directions used for the characterizations presented here represent persistent winds ( 10 or 30 min averages) and are generally consistent with winds measured at other ground stations in Houston and with back trajectories. It is admittedly difficult to establish source region or direction based on local wind measurements, so we focused here on periods of reasonably consistent (over $1-3 \mathrm{~h}$ ) wind direction, or clear patterns of oscillatory direction.

Each period in Table 1 is defined by a specific temporal pattern in wind direction. These patterns and the variation of the Ångström exponent were weighted approximately equally in the initial putative selection of the period divisions. (Atkinson et al., in preparation) For Periods 1 and 5, the wind direction was dominated by southerly winds, as shown in Fig. 3, while Period 2 was dominated by northerly winds. Periods 3 and 4 have similar average wind directions and times in different wind direction bins but different temporal signatures. In Period 3, the wind direction shifted over the course of each day between North and South, following the coastal oscillation pattern (land-sea breeze) that is a familiar feature of HGB meteorology. The wind shift in Period 4 took place over a much longer timescale. Other analyses of higher level winds and at a coastal station also have implicated the importance of the land-sea breeze in Period 2. (Day et al., 2010; Rappenglück et al., 2008).

The original divisions into the periods in Table 1 were somewhat arbitrary; to support their assignment, a change point analysis 


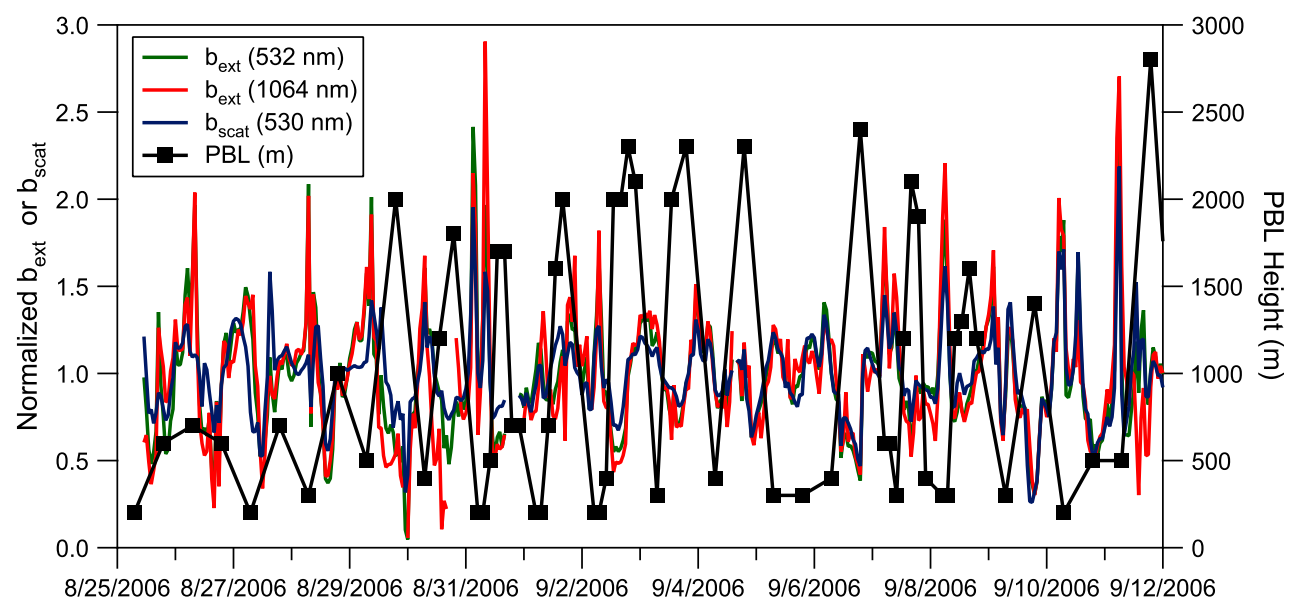

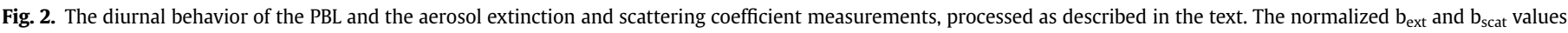
are unitless ratios.

(CPA) was conducted, as described in more detail in the Supplementary Material. The results of the CPA are shown in Fig. 4 and summarized in Table A1 (in the Supplementary Material). The CPA procedure is used to identify changes in the long-term trend in observable metrics and to quantify the uncertainty of the assignment of the border between periods. The analysis incorporates a cumulative sum plot, as shown in Fig. 4, and the calculation of the mean square error, which should be minimized when the data is split at a natural change point. This process is then repeated after a random reorganization of the data to test for the uniqueness of the chosen separation point. The latter process provides a statistical measure of the certainty of the change point assignment; and all changes reported here were supported at confidence levels $>90 \%$ in at least one observable quantity other than wind direction.

Period 1 (25 August-29 August 2006) is remarkable in that the maxima in both of the extinction coefficients (532 and $1064 \mathrm{~nm}$ ) are large but the $530 \mathrm{~nm}$ scattering coefficient maximum is proportionally smaller (Fig. 1). This is characteristic of either highly absorbing or large particles. The data from the Grimm-PAS instrument for the size bins between 1 and $4 \mu \mathrm{m}$ (Fig. 5 top) confirm the presence of significant number concentrations of larger particles. The $532 \mathrm{~nm}$ extinction coefficient is converted to a predicted mass (using a mass extinction coefficient of $6.3 \mathrm{~m}^{2} \mathrm{~g}^{-1}$ derived from a correlation with the CAMS data), and this mass and the CAMS results are compared to those from the Q-AMS and SMPS in Fig. 5 (bottom). The aerosol measured during this time period was characterized by the influence of LRT of Saharan dust and sea salt. This was confirmed by researchers aboard the R/V Ronald $H$. Brown (RHB) in the Gulf of Mexico (Bates et al., 2008; Massoli, in press) and the aerosol appears to have had a significant inland influence. As expected, the Q-AMS and the SMPS did not observe the super- micron dust particles, but the SMPS shows slightly larger mass loadings, consistent with some refractory particles in the submicron range, as expected for dust and sea salt. Qualitative agreement between the CRDT and CAMS monitors on some days shows that both are influenced by the super-micron particles but that they are not spatially homogeneous with time.

Although period 1 would appear to be heavily polluted based on the CAMS measurements, nearing the 24-h average standard of $35 \mu \mathrm{g} \mathrm{m}^{-3}$ on 28 August 2006, it was actually a very clean period based on the TRAMP gas-phase chemical measurements. A number of human-health-relevant trace gas average concentrations for the periods are shown in Table 2, and all are at their lowest levels during period 1 . Intuitively, it would seem that the direct public health effects of dust aerosols would be significantly less than other (especially combustion related) aerosol types, but this appears to be far from certain. (Duzgoren-Aydin, 2008; Seagrave et al., 2008) If this is the case, period 1 would serve as a caution about the applicability of a purely mass-based PM standard.

Period 2 (29 August-6 September 2006) was initiated by a frontal passage that resulted in a shift in the prevailing wind to the North and NE. (Rappenglück et al., 2008) Early on, this resulted in a very low aerosol background, but during the early morning of 31 August 2006, dramatic increases in the aerosol number and mass concentrations and extinction coefficients were observed (Fig. 6). The Ångström exponent was also observed to increase (greater contribution to extinction from smaller particle sizes) during this period by the CRD instrument aboard the RHB and the TRAMP CRDT/N instrument. (Atkinson et al., in preparation) Backtrajectory analysis is consistent with transport of polluted air from over the continent, (Stohl and Eckhardt, 2008) throughout the lower troposphere; but there is also evidence of the land-sea breeze

Table 1

Summary of periods by wind direction and wind speed.

\begin{tabular}{|c|c|c|c|c|c|c|}
\hline Period & 1 & 2 & 3 & 4 & 5 & Study \\
\hline$\overline{\text { Start Date (CDT) }}$ & $8 / 25 / 06,0: 00$ & $8 / 29 / 06,13: 00$ & $9 / 6 / 06,21: 00$ & 9/11/06, 0:00 & $9 / 15 / 06,13: 00$ & $8 / 25 / 06,0: 00$ \\
\hline End Date (CDT) & $8 / 29 / 06,12: 00$ & $9 / 6 / 06,20: 00$ & 9/10/06, 23:00 & $9 / 15 / 06,12: 00$ & $9 / 23 / 06,23: 00$ & $9 / 23 / 06,23: 00$ \\
\hline Total Hours & 109 & 176 & 75 & 109 & 201 & 670 \\
\hline Ave Wind Speed $\left(\mathrm{m} \mathrm{s}^{-1}\right)$ & 3.44 & 2.66 & 2.89 & 2.62 & 4.66 & 3.41 \\
\hline Hours from N (315-360 deg and 0-45 deg) & 0 & 88 & 19 & 32 & 33 & 172 \\
\hline Hours from NE (45-90 deg) & 0 & 31 & 14 & 14 & 14 & 75 \\
\hline Hours from SE (90-135 deg) & 5 & 16 & 0 & 8 & 6 & 35 \\
\hline Hours from S (135-225 deg) & 87 & 20 & 22 & 18 & 126 & 273 \\
\hline Hours from SW (225-270 deg) & 1 & 11 & 18 & 19 & 14 & 63 \\
\hline Hours from NW (270-315 deg) & 16 & 10 & 2 & 18 & 8 & 54 \\
\hline
\end{tabular}



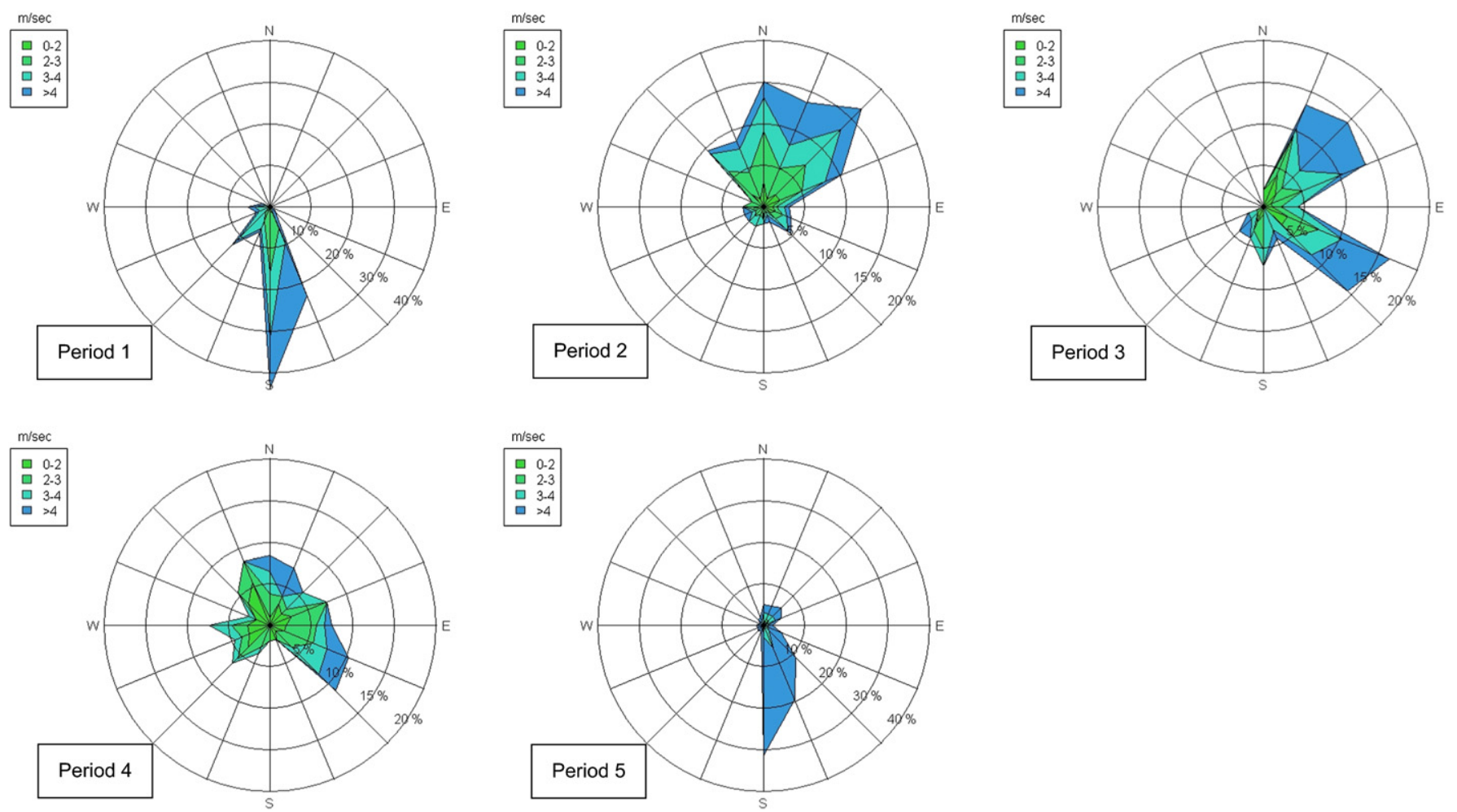

Fig. 3. Wind speed wind roses for the five periods discussed in the text.

pattern confined to the lower atmospheric layers $(<1.5-2 \mathrm{~km})$ on a local up to regional scale. (Bates et al., 2008; Day et al., 2010; Rappenglück et al., 2008) Both cases can lead to the delivery of processed aerosol to $\mathrm{HGB}$, and either possibility is supported by the $\mathrm{NO}_{x} / \mathrm{NO}_{y}$ ratio, a tracer for aged airmasses. The period-average decreased subtly (from 0.88 to 0.83 ) compared to the first period, but the hourly averages were sometimes below 0.33 during Period 2 , indicating significant oxidative conversion (especially given the large $\mathrm{NO}_{x}$ sources in the HGB area.) Ozone attains the maximum period-average concentration during this period, presumably due to the influx of background ozone and photochemically active species that add to the already potent Houston emissions mixture.

During periods with more pollution, such as period 2, conditions may lead to local aerosol concentrations increasing to such an extent that a specific site is in non-compliance with the $\mathrm{PM}_{2.5}$ 24-h standard. For example, more mass is registered at the TRAMP site (24-h average AMS total mass $=15.8 \mu \mathrm{g} \mathrm{m}^{-3}$ ) than in the composite CAMS average $\left(13.1 \mu \mathrm{g} \mathrm{m}^{-3}\right)$ on 31 August 2006. This geographic heterogeneity can occur as a result of primary emission of particles, condensation of low volatility vapors at temperatures cooler than

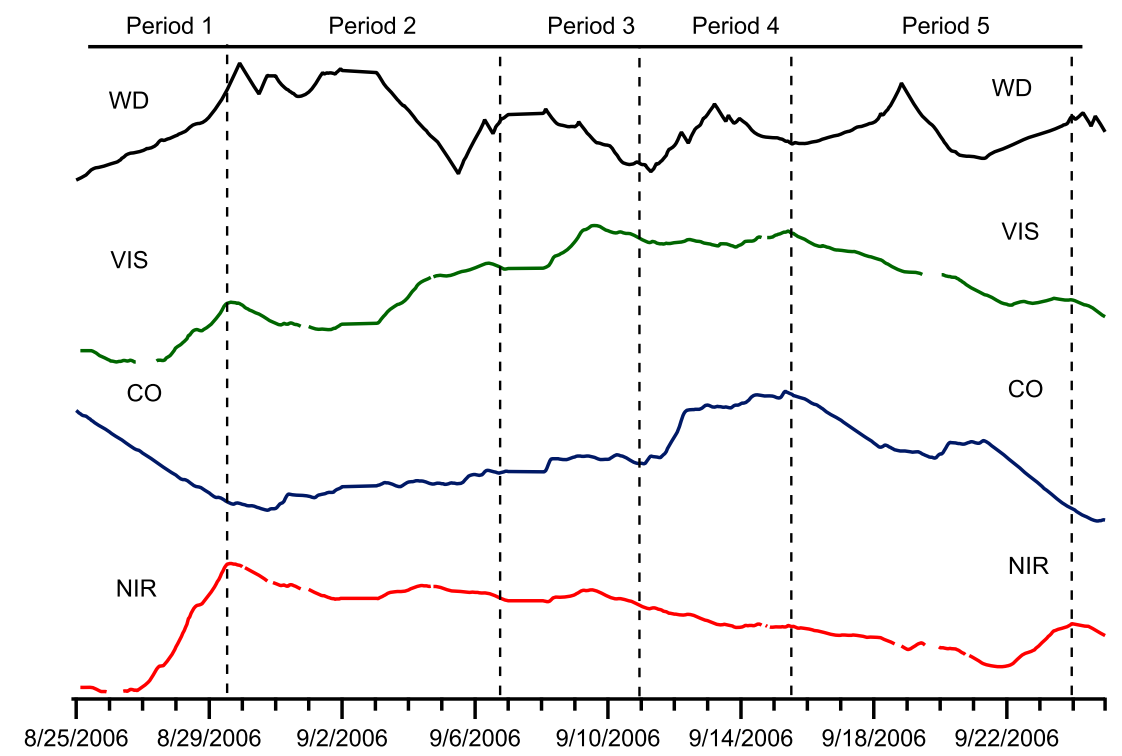

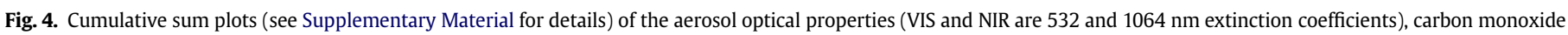
(CO) mixing ratio, and the wind direction (WD) during the TRAMP study period. 


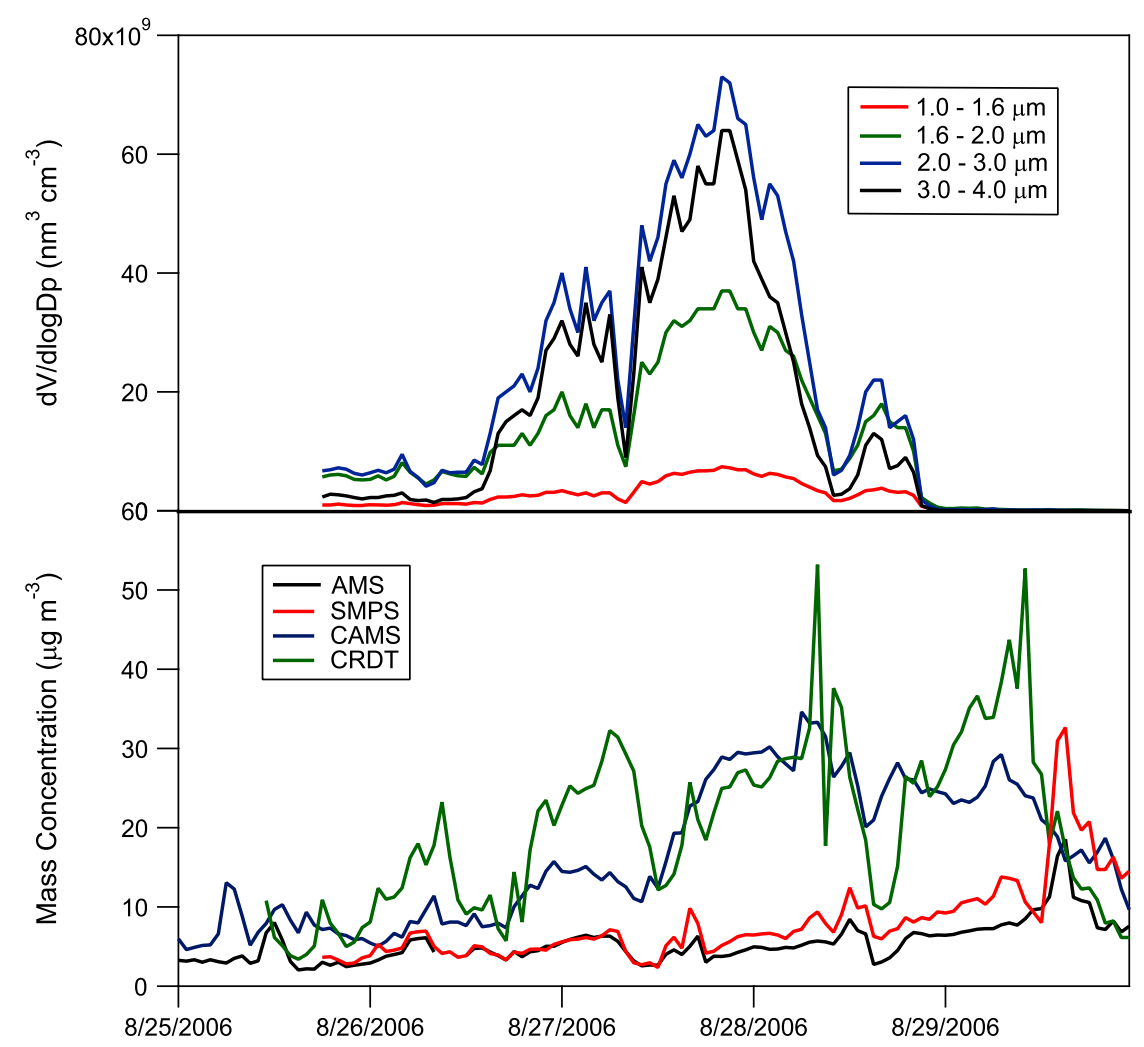

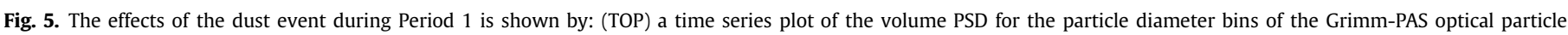

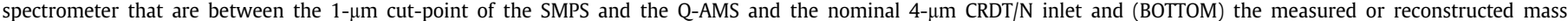
concentrations during this time period. The PAS went offline during the night of 28 August 2006.

that of the stack (assuming this outweights dilution), or formation of secondary non- or semi-volatile material that partitions to the condensed phase. In the latter case, for example, oxidation of $\mathrm{SO}_{2}$ and VOCs can lead to addition of mass to the pre-existing aerosol (and a corresponding increase in extinction). Two events during period 2 are investigated for 31 August 2006 (chosen as a case in point, Fig. 6) to illustrate these processes. Following two rapid wind shifts at about 2:00 and 3:00 (CDT), the mixing ratios of a number of VOCs dramatically increased (not shown), presumably due to

Table 2

Gas-phase species statistics for each period, based on one-hour averages of $60 \mathrm{~s}$ data.

\begin{tabular}{|c|c|c|c|c|c|c|}
\hline Period & 1 & 2 & 3 & 4 & 5 & Study \\
\hline Average NO (ppbv) & 1.51 & 2.75 & 2.83 & 10.10 & 2.97 & 3.73 \\
\hline Minimum & 0.02 & 0.01 & 0.01 & 0.05 & 0.02 & 0.01 \\
\hline Maximum & 12.10 & 61.24 & 23.89 & 72.03 & 52.43 & 72.03 \\
\hline Average $\mathrm{NO}_{2}$ (ppbv) & 5.37 & 16.14 & 14.93 & 21.73 & 9.82 & 13.36 \\
\hline Minimum & 0.86 & 1.48 & 2.13 & 3.50 & 0.89 & 0.86 \\
\hline Maximum & 14.21 & 72.02 & 47.81 & 53.87 & 56.65 & 72.02 \\
\hline Average NOy (ppbv) & 7.83 & 22.59 & 21.98 & 36.72 & 14.50 & 20.04 \\
\hline Minimum & 1.84 & 4.76 & 6.20 & 9.13 & 1.48 & 1.48 \\
\hline Maximum & 26.28 & 78.92 & 74.76 & 90.37 & 96.31 & 96.31 \\
\hline Average CO (ppbv) & 140.14 & 294.46 & 288.65 & 350.11 & 183.58 & 248.16 \\
\hline Minimum & 97.28 & 188.94 & 130.57 & 122.66 & 81.32 & 81.32 \\
\hline Maximum & 294.13 & 626.85 & 904.18 & 991.17 & 682.95 & 991.17 \\
\hline Average $\mathrm{O}_{3}$ (ppbv) & 15.07 & 45.62 & 42.26 & 30.42 & 21.81 & 31.54 \\
\hline Minimum & 2.84 & 4.06 & 1.98 & 2.03 & 2.33 & 1.98 \\
\hline Maximum & 31.87 & 127.53 & 131.93 & 101.20 & 92.58 & 131.93 \\
\hline Average $\mathrm{SO}_{2}$ (ppbv) & 0.95 & 2.78 & 4.52 & 4.39 & 1.00 & 2.48 \\
\hline Minimum & 0.00 & 0.17 & 0.14 & 0.23 & 0.00 & 0.00 \\
\hline Maximum & 12.54 & 35.32 & 77.53 & 68.25 & 8.41 & 77.53 \\
\hline
\end{tabular}

transport from the HSC. Note that there was already a substantial amount of mass in both the sub-200 nm ("Aitken") and 200-1000 nm ("accumulation") organic aerosol bin sums measured by the Q-AMS. As the VOC levels increased, a corresponding increase in the organic mass concentration in both size ranges is observed. The ratio of the Q-AMS signal at $m / z 44$ to that at 57 is a qualitative indicator of the relative extent of oxidation of the organic material in the aerosol. In general, this value peaks in the middle of the afternoon, when photochemistry is strongest. During the event in question, the value of this ratio is depressed relative to its maximum value but slightly enhanced relative to the minimum values typically representative of primary, hydrocarbon-like organic aerosol. This indicates the possibility of non-photochemical formation of secondary organic aerosol (resulting in milder oxidation) or a mixture of primary emission and secondary formation of organic aerosol during this event.

Oxidation of $\mathrm{SO}_{2}$ appears to play a minor role in the particle mass concentration increase in the above early-morning episode, in contrast to events observed during TexAQS 2000. (Brock et al., 2003) Between 6:00 and 10:00, however, the wind direction slowly drifted from $\mathrm{NE}$ to $\mathrm{E}$, bringing large concentrations of both $\mathrm{SO}_{2}$ ( $>25 \mathrm{ppbv}$ ) and various VOCs from sources in the HSC. During this episode, both sulfate and organic masses increased, suggestive of the type of event described by Brock et al. (2003) during which new particle formation may be driven by $\mathrm{OH}$ initiated oxidation of $\mathrm{SO}_{2}$ followed by condensation, neutralization, and possibly addition of organic compounds. While this scenario is supported by the increase in the ratio of the Q-AMS signals at $m / z 44$ and 57 over this time period, primary organic particle emission can not be ruled out based on this analysis. A number of similar episodes were observed during the study, one of which is discussed in more detail below. 


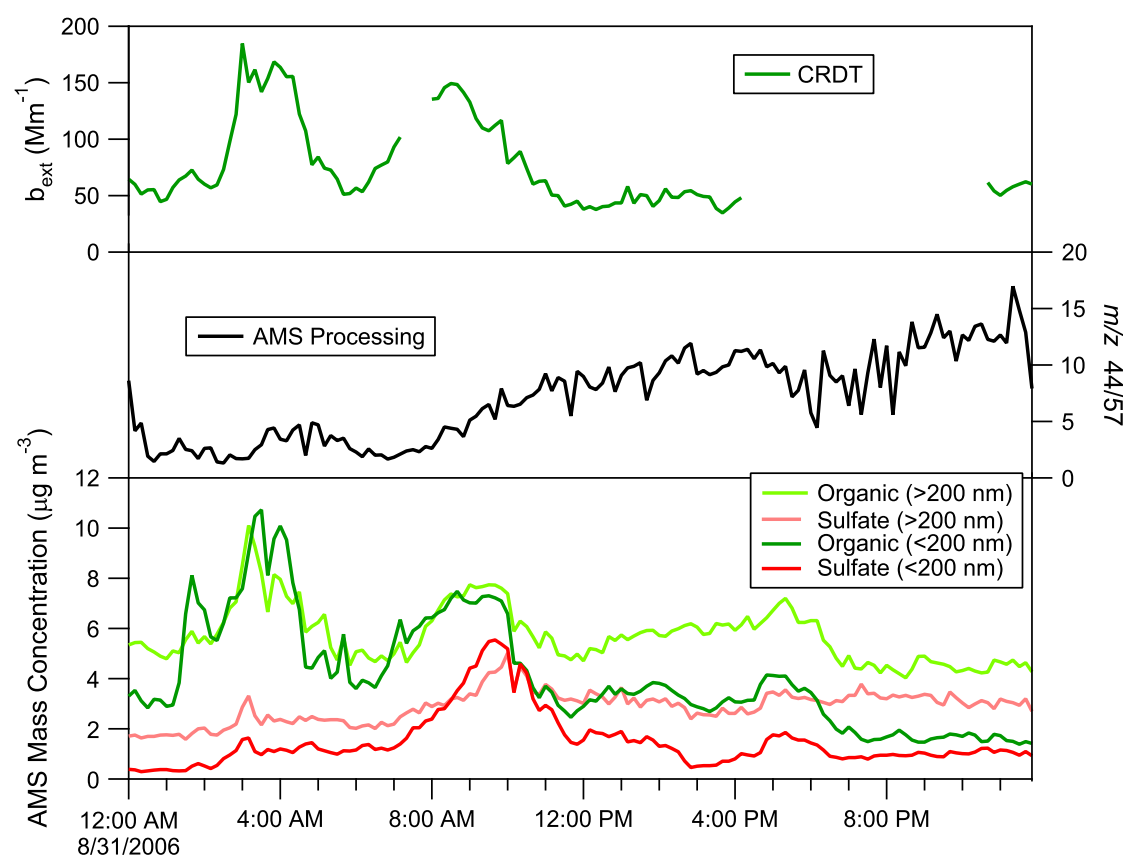

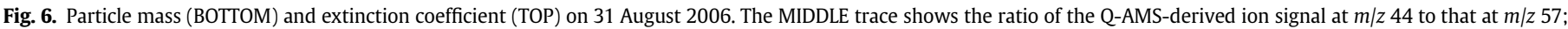
this ratio is used as a qualitative indication of the level of oxidation of the organic aerosol.

Period 3 (6 September-10 September 2006) featured substantial ozone formation and observation of fine-mode dominated aerosol mass and optical properties by instruments at the TRAMP site (see Tables 2 and 3 ) and on the RHB. (Atkinson et al., in preparation; Bates et al., in press; Lefer and Rappenglück, 2010) In this case, it seems highly likely that recirculation of the polluted air mass on a multi-day cycle is responsible for the provision of both fine-mode background PM and of the ozone precursors that lead to rapid and efficient ozone formation. As noted above, transport of $\mathrm{SO}_{2}$ and organic material from the HSC can be associated with increases of

Table 3

Statistics for ambient aerosol optical properties and particle number concentration for each period.

\begin{tabular}{|c|c|c|c|c|c|c|}
\hline Period & 1 & 2 & 3 & 4 & 5 & Study \\
\hline $\begin{array}{l}\text { Mean } \mathrm{b}_{\text {ext,532 }} \\
\left(\mathrm{Mm}^{-1}\right)\end{array}$ & 129.9 & 109.5 & 124.9 & 95.8 & 65.0 & 100.8 \\
\hline Minimum & 21.3 & 2.6 & 25.8 & 17.2 & 8.4 & 2.6 \\
\hline Maximum & 332.8 & 256.0 & 305.6 & 197.0 & 131.5 & 332.8 \\
\hline $\begin{array}{l}\text { Mean } \mathrm{b}_{\text {ext, } 1064} \\
\quad\left(\mathrm{Mm}^{-1}\right)\end{array}$ & 76.2 & 28.0 & 32.6 & 28.8 & 34.7 & 37.7 \\
\hline Minimum & 9.9 & 1.0 & 7.3 & 7.6 & 0.1 & 0.1 \\
\hline Maximum & 223.6 & 70.5 & 87.5 & 67.1 & 84.9 & 223.6 \\
\hline $\begin{array}{l}\text { Mean } \mathrm{b}_{\text {scat, }} 530 \\
\quad\left(\mathrm{Mm}^{-1}\right)\end{array}$ & 48.2 & 80.0 & 79.9 & $\mathbf{5 5 . 0}$ & 28.5 & $\mathbf{5 7 . 8}$ \\
\hline Minimum & 15.6 & 13.7 & 12.8 & 18.8 & 8.5 & 8.5 \\
\hline Maximum & 94.5 & 166.7 & 177.5 & 136.7 & 59.0 & 177.5 \\
\hline Mean PN $\left(\# \mathrm{~cm}^{-3}\right)$ & 12,330 & 28,267 & 30,523 & 32,487 & 18,176 & 24,393 \\
\hline Minimum & 3599 & 6576 & 7132 & 11094 & 1704 & 1704 \\
\hline Maximum & 45,152 & 10,0149 & 14,2304 & 10,8244 & 11,3958 & 14,2304 \\
\hline $\begin{array}{l}\text { Mean Q-AMS mass } \\
\quad\left(\mu \mathrm{g} \mathrm{m}^{-3}\right)\end{array}$ & 4.87 & 15.12 & 14.84 & 11.39 & 7.46 & 11.22 \\
\hline Minimum & 2.05 & 6.85 & 3.37 & 3.33 & 1.64 & 1.64 \\
\hline Maximum & 9.80 & 30.67 & 35.39 & 34.61 & 24.18 & 35.39 \\
\hline $\begin{array}{l}\text { Mean SMPS volume } \\
\quad\left(\mathrm{nm}^{3} \mathrm{~m}^{-3}\right)\end{array}$ & 4398 & 11,499 & 12,223 & 12,294 & 6071 & 9291 \\
\hline Minimum & 4635 & 5264 & 2585 & 2507 & 1465 & 1465 \\
\hline Maximum & 53,183 & 27,286 & 23,318 & 30,433 & 39,363 & 39,363 \\
\hline
\end{tabular}

sulfate and organic aerosol mass concentrations, and a semi-quantitative analysis of this process is provided by examination of data during easterly flow, predominantly on 7 September 2006.

In Fig. 7, the $\mathrm{SO}_{2}$ concentrations for the whole study period are shown. Concentrations are generally at background levels (1-3 ppbv) except for narrow spikes that occur when the wind direction is $\sim 60$ degrees (ENE). Given the number and composite strength of the sources clustered in the HSC (shown as brown dots in the upper right inset to Fig. 7) this result seems reasonable. Increases in the visible extinction and scattering coefficients (shown as the left top inset in Fig. 7) are correlated $\left(R^{2}>0.8\right)$ with the $\mathrm{SO}_{2}$ concentration during the periods indicated by the arrows in Fig. 7. The sulfate mass concentration from the Q-AMS is also correlated with $\mathrm{SO}_{2}$ during these periods but with a smaller correlation coefficient $\left(R^{2}=0.34\right)$. These observations are suggestive of increases in sulfate aerosol mass during the short transit time from the sources in the HSC to the TRAMP site. (Another possibility would be primary emissions of sulfate aerosol that were synchronous with the emissions of $\mathrm{SO}_{2}$, but these were not observed during TexAQS 2000. (Brock et al., 2003))

The wind speeds during these periods were uniformly low (average of $2.5 \mathrm{~m} \mathrm{~s}^{-1}$, standard deviation of $0.6 \mathrm{~m} \mathrm{~s}^{-1}$ and with only one point outside of the $\pm 1 \sigma$ confidence limits at $3.6 \mathrm{~m} \mathrm{~s}^{-1}$ ) and predominantly from the ENE. If a mean source to receptor distance of $20 \mathrm{~km}$ (a reasonable average distance to sources in the HSC) is assumed, the transit time would be $\sim 5.5 \mathrm{~h}$. Using a discrete form of the rate expression for the $\mathrm{SO}_{2}$ oxidation rate (based only on $\mathrm{OH}$ oxidation) as in Brock et al. (2008)

$\mathrm{dSO}_{4}^{2-} / \mathrm{dt} \sim \Delta \mathrm{SO}_{4}^{2-} / \Delta \mathrm{t}=10^{-12} \mathrm{~cm}^{3} \mathrm{molec}^{-1} \mathrm{~s}^{-1} * \mathrm{SO}_{2} * \mathrm{OH}$

where $\mathrm{SO}_{2}$ and $\mathrm{OH}$ are the number concentrations for the two reagents, the incremental increase in the sulfate mass concentration during the transit from the HSC can be calculated. Using the mean daytime 7 September $2006 \mathrm{OH}$ value (measured by a low pressure laser induced fluorescence instrument) of 0.2 pptv $\left(5 \times 10^{6}\right.$ molec $\left.\mathrm{cm}^{-3}\right)$ and a mean value for the 7 September 2006 


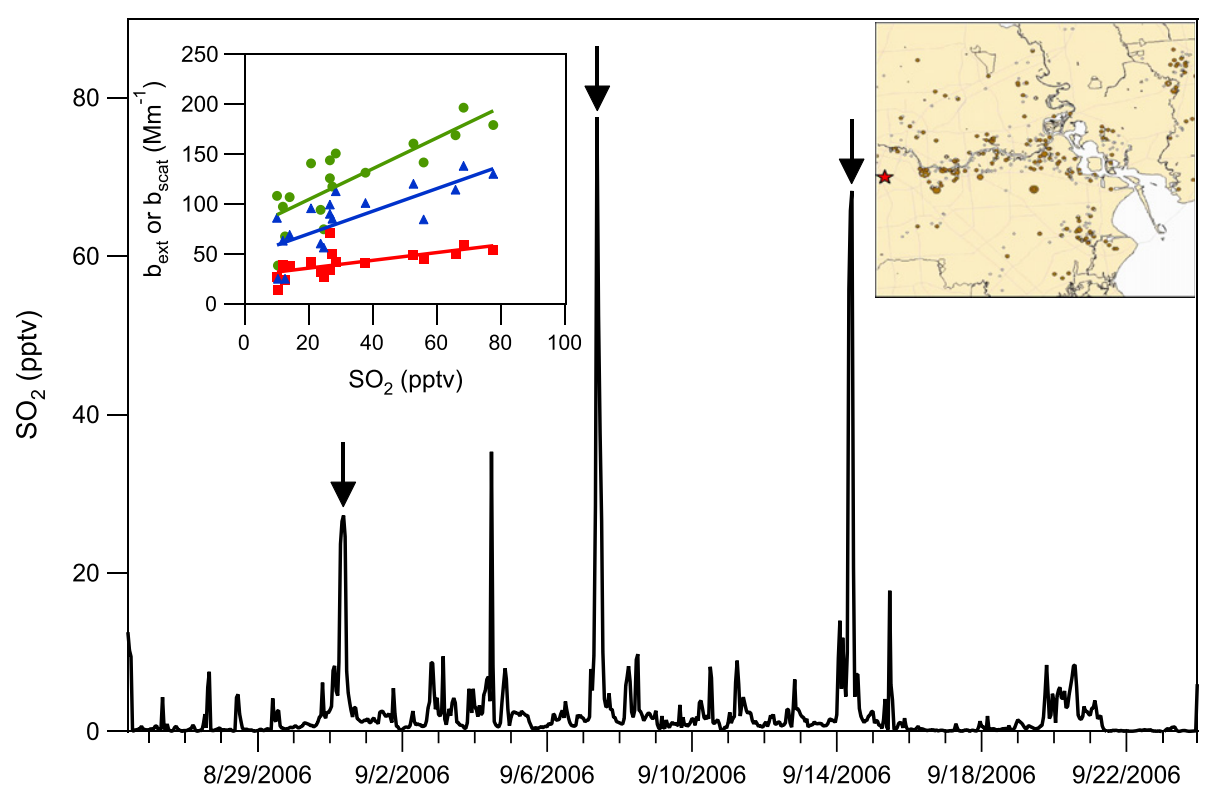

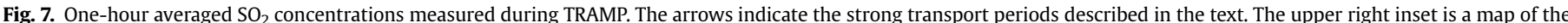

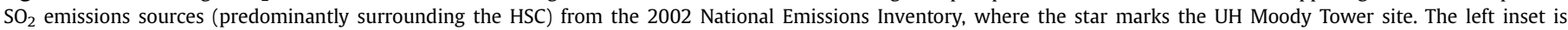

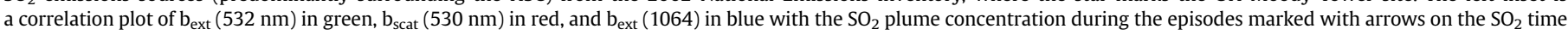
series.

$\mathrm{SO}_{2}$ plume of $40 \mathrm{ppbv}\left(10^{12}\right.$ molec $\left.\mathrm{cm}^{-3}\right)$ predicts a sulfate increase of $15.9 \mu \mathrm{g} \mathrm{m}^{-3}$, on the same order of magnitude as the $\sim 6 \mu \mathrm{g} \mathrm{m}^{-3}$ increase above the background level observed by the Q-AMS and that predicted by the CRDT/N (an increase in $b_{\text {ext }}$ of $50 \mathrm{Mm}^{-1}$ at $532 \mathrm{~nm}$ corresponds to $7.5 \mu \mathrm{g} \mathrm{m}^{-3}$ ). This is a rough calculation that only takes into account the oxidation of $\mathrm{SO}_{2}$, not the subsequent steps that are necessary to increase sulfate aerosol mass observable by the Q-AMS or the CRDT/N or possible depositional/diffusional losses of $\mathrm{SO}_{2}$ and sulfate aerosol. Thus, this calculation represents a realistic upper bound for the expected increase in sulfate aerosol measured in the plume at the Moody Tower site. However, the order of magnitude agreement obtained suggests that production of sulfate could be occurring during advection to the city from the HSC. This has implications for $\mathrm{PM}_{2.5}$ production in HGB, particularly since the growth in sulfate appears to be accompanied by increases in organic aerosol (as shown in Fig. 7) that might be expected to have a more significant human health effect than the sulfate. (Baltensperger et al., 2008 and references therein) As noted above, the observed increases in aerosol mass-related properties suggest that transport of pollutants from the HSC to the city could lead to local 24-h $\mathrm{PM}_{2.5}$ exceedances.

Because of the similarity between periods 2 and 3, it is possible that the split (based on TRAMP wind directions and Q-AMS sulfate mass - not shown) is spurious, as concluded by Bates et al. (2008). If this is the case, interstate transport or recirculation would probably replace LRT of aged pollution aerosol as a source of the background aerosol in Period 2. It is possible, however, that the background pollution produced by northerly continental flow and recirculation is difficult to distinguish and has similar effects on the production of $\mathrm{PM}_{2.5}$ relevant aerosol in the HGB area.

Period 4 (11 September-15 September) was characterized by more slowly varying wind direction and the highest values for the study of combustion-related trace gas concentrations $\left(\mathrm{NO}_{x}, \mathrm{NO}_{y}\right.$, $\mathrm{CO}$; see Table 2). The elevated CO suggested LRT of biomass burning plumes from forest and field fires burning across the western U.S. and Canada at that time in 2006. Because the wildfires were widely scattered, including several in Northeast Texas and Louisiana, the FLEXPART "fire-CO" product was inconclusive about specific source areas. However, the suggestion of biomass burning influence is supported. (Stohl and Eckhardt, 2008) The extensive aerosol properties (Table 3 ) are indicative of a more highly absorbing aerosol in that the ratios of the extinction (scattering plus absorption) coefficients to the scattering coefficient are larger than in the prior two periods (for the $532 \mathrm{~nm}$ measurements $1.74 \mathrm{vs} .1 .37$ and 1.56.) As mentioned earlier, this can also be caused by the presence of larger particles that increase the $1064 \mathrm{~nm}$ extinction coefficient (absolute and relative to the $532 \mathrm{~nm}$ measurement) and lead to potentially large negative measurement errors in the scattering coefficient. Unfortunately, the Grimm PAS was offline during this period, so direct confirmation of fine particle domination of the optical properties is not available. However, the agreement between the CAMS, Q-AMS, and SMPS-derived masses (Fig. 1 middle panel) during this period argues that super-micron particles were not present in large concentration because this causes these measurements to diverge, as shown in Fig. 5.

This measurement period points out a problem with using aerosol optical extinction-related measures (such as those presented here or aerosol optical depths derived from sunphotometers) to quantify aerosol loadings. The effects of large particles and absorbing particles are similar, for both the extensive properties and intensive measures derived from their spectral variation, and disentangling the two effects can be challenging without supporting information. (Atkinson et al., in preparation) The particle refractive index plays a key role, and its measurement in the ambient atmosphere is still a significant challenge. An abrupt shift to predominantly southerly wind at the end of this period was closely followed by a precipitous drop in all of the aerosol measurements, indicating a termination of the continental biomass burning effect.

Period 5 (15 September-24 September 2006) was the longest of the study and was a relatively clean period from both the aerosol and gas-phase chemical standpoint. As mentioned earlier, increasingly strong southerly winds (except on 18-20 September) appear to have lead to a clearing effect, producing low trace gas period-averaged concentrations similar to those measured during 
the first period. Despite the southerly winds, the dust influence was not as pronounced as during period 1 . However, during two days near the end of the period (22 September and 23 September 2006), the aerosol and chemical measurements (not shown) strongly resembled the first period, with higher values of both the $532 \mathrm{~nm}$ and $1064 \mathrm{~nm}$ extinction coefficients and relatively low scattering coefficient, SMPS volume, and Q-AMS mass concentrations. The Grimm PAS was offline on 23 September but registered large supermicron (1-4 $\mu \mathrm{m}$ particle diameter) number concentrations on 22 September 2006, with a pattern similar to that shown in Fig. 5.

\section{Conclusions}

Meteorology and LRT of aerosol to the HGB region play an important role in the extant aerosol optical properties and measured mass concentrations. This could have consequences for compliance with the newly revised PM NAAQS. On the other hand, the unique mixture of emitted compounds and active oxidative photochemistry in HGB can produce rapid increases in aerosol mass concentration that can lead to significant increases in the measured $\mathrm{PM}_{2.5}$ in the city (perhaps even for a subset of the CAMS stations) under some meteorological conditions. Multi-day recirculation produced by low winds and the land-sea breeze pattern seems to augment the ability to produce enhanced aerosol mass concentrations from the HSC emissions. This positive feedback cycle probably has the most serious implications for human health in HGB of any examined here.

\section{Acknowledgements}

The authors would like to express their gratitude to the Houston Advanced Research Center (HARC) for supporting and funding Projects H78. In addition we would like to thank the Texas Commission on Environmental Quality (TCEQ) for supporting and funding this research under grant 582-5-64594. DBA acknowledges support from the Atmospheric Composition and Climate program at the National Atmospheric and Oceanic Administration through award number NA05OAR4310108.

\section{Appendix. Supplementary data}

Supplementary data associated with this article can be found in the online version, at doi:10.1016/j.atmosenv.2008.12.055.

\section{References}

Anderson, T.L., Ogren, J.A., 1998. Determining aerosol radiative properties using the TSI 3563 integrating nephelometer. Aerosol Sci. Technol. 29, 57-69.

Atkinson, D.B., et al. Comparison of Aerosol Ångström Exponent Products From In Situ Extinction Instruments and Sunphotometers during TexAQS-GoMACCS 2006 - Testing Parameterizations for the Estimation of Effective Particle Radii. J. Geophys. Res., in preparation.
Baltensperger, U., et al., 2008. Combined determination of the chemical composition and of health effects of secondary organic aerosols: the POLYSOA project. J. Aerosol Med. Pulm. Drug Deliv. 21, 145-154.

Bates, T.S., et al., 2008. Boundary layer aerosol chemistry during TexAQS/GoMACCS 2006: Insights into aerosol sources and transformation processes. J. Geophys. Res.-Atmos. 113.

Brock, C.A., et al., 2003. Particle growth in urban and industrial plumes in Texas. J. Geophys. Res. Atmos. 108.

Brock, C.A., et al., 2008. Sources of particulate matter in the northeastern United States in summer: 2. Evolution of chemical and microphysical properties. J. Geophys. Res. Atmos. 113.

Byun, D.W., et al., 2007. Evaluation of air quality models for the simulation of a high ozone episode in the Houston metropolitan area. Atmos. Environ. 41, 837-853.

Daum, P.H., et al., 2004. Origin and properties of plumes of high ozone observed during the Texas 2000 Air Quality Study (TexAQS 2000). J. Geophys. Res. Atmos. 109, 21.

Day, B.M., et al., 2010. Characteristics of the Nocturnal Boundary Layer in Houston, Texas during TexAQS II. Atmos. Environ. 44, 4014-4023.

DeCarlo, P.F., et al., 2004. Particle morphology and density characterization by combined mobility and aerodynamic diameter measurements. Part 1 : Theory. Aerosol Sci. Technol. 38, 1185-1205.

Duzgoren-Aydin, N.S., 2008. Health effects of atmospheric particulates: a medica geology perspective. J. Environ. Sci. Health. Part C-Environmental Carcinogenesis \& Ecotoxicology Rev. 26, 1-39.

EPA. 1995. Guidance for ambient monitoring, edited.

EPA, 2007. 40 CFR Part 51 clean air fine particle Implementation Rule, edited.

Flynn, J., 2008. Impacts of Clouds and aerosols on ozone photochemistry in Southeast Texas, M.S. thesis, University of Houston, Houston. 57 pp.

Guenther, A.B., et al., 1993. Isoprene and monoterpene emission rate variability model evaluations and sensitivity analyses. J. Geophys. Res. Atmos. 98, 12609-12617.

Heintzenberg, J., et al., 2006. Intercomparisons and aerosol calibrations of 12 commercial integrating nephelometers of three manufacturers. J. Atmos. Ocean. Technol. 23, 902-914.

Jayne, J.T., et al., 2000. Development of an aerosol mass spectrometer for size and composition analysis of submicron particles. Aerosol Sci. Technol. 33, 49-70.

Jimenez, J.L., et al., 2003. Ambient aerosol sampling using the aerodyne aerosol mass spectrometer. J. Geophys. Res. Atmos. 108.

Lefer, B, Rappenglück, B, 2008. Overview of TRAMP Texas II study. Atmos. Environ. in this issue.

Leuchner, M., Rappenglück, B., 2010. VOC source-receptor Relationships in Houston during TexAQS-II. Atmos. Environ 44, 4056-4067.

Massoli, P. Aerosol optical and hygroscopic properties during TexAQS-GoMACCS 2006 and their impact on aerosol direct radiative forcing. J. Geophys. Res., in press.

Peters, T.M., et al., 2006. Comparison of the Grimm 1.108 and 1.109 portable aerosol spectrometer to the TSI 3321 aerodynamic particle sizer for dry particles. Ann. Occup. Hyg. 50, 843-850.

Radney, J.G., et al., 2009. Laboratory validation of aerosol extinction coefficient measurements by a field-deployable pulsed cavity ring-down transmissometer. Aerosol Sci. Technol. 43, 71-80.

Rappengluck, B., et al., 2008. An analysis of the vertical structure of the atmosphere and the upper-level meteorology and their impact on surface ozone levels in Houston, Texas. J. Geophys. Res.-Atmos. 113.

Seagrave, J., et al., 2008. Oxidative stress, inflammation, and pulmonary function assessment in rats exposed to laboratory-generated pollutant mixtures. J. Toxicol. Environ. Health-Part A-Current Issue. 71, 1352-1362.

Smith, J.D., Atkinson, D.B., 2001. A portable pulsed cavity ring-down transmissometer for measurement of the optical extinction of the atmospheric aerosol. Analyst 126, 1216-1220.

Stohl, A., Eckhardt, S., 2008. The NILU Atmospheric Backward Transport Analysis Products for TEXAQS. http://zardoz.nilu.no/ andreas/TEXAQS/index.html: http://zardoz.nilu.no/ andreas/TEXAQS/index.html (accessed 09.22.2008).

Ziemba, L.D., 2010. Heterogeneous conversion of nitric acid to nitrous acid on the surface of primary organic aerosol in an urban atmosphere. Atmos Environ 44 4081-4089. 